\title{
Variation of runoff between southern and northern China and their attribution in the Qinling Mountains, China
}

\author{
Yi $\mathrm{He}^{1}$, Yiyi $\mathrm{Hu}^{2}$, Jinxi Song ${ }^{3}$, and Xiaohui Jiang ${ }^{2}$ \\ ${ }^{1}$ College of Urban and Environmental Sciences, Northwest University \\ ${ }^{2}$ Shaanxi Key Laboratory of Earth Surface System and Environmental Carrying Capacity \\ ${ }^{3}$ Northwest University
}

February 24, 2021

\begin{abstract}
Climate and underlying surface changes have a profound impact on runoff in the Qinling Mountains. This study attempts to identify the difference in runoff changes of two rivers in the south and north of China's south-north transitional zone under climate change. The Pettit test and Mann-Kendall test were used to investigate the abrupt change and trend analysis on runoff in the Ba River watershed and Jinqian River watershed from 1960 to 2014 . The coupled energy-water balance equation based on the Budyko hypothesis estimated the climate and landscape elasticity of runoff followed by attribution analysis of runoff in these two watersheds. The results showed that annual runoff in the Jinqian River (in the southern Qinling Mountains) and the Ba River (in the northern Qinling Mountains) exhibited a significant decreasing trend at $\mathrm{P}<0.05$ and $\mathrm{P}<0.01$, respectively. Abrupt runoff changes occurred in 1989 and 1992 in the Ba River and Jinqian River, respectively. The attribution analysis showed that the change in potential evapotranspiration had little impact on runoff in the southern and northern Qinling Mountains. In contrast, the dominant factors leading to runoff reduction were the change in precipitation and catchment landscape. The contributions of climate change and land surface alteration to runoff changes in the Ba River watershed and Jinqian watershed were $38.08 \%$ and $61.92 \%$, and $23.95 \%$ and $76.05 \%$, respectively. This study can provide a scientific reference for water resource protection in the south-north transitional zone.
\end{abstract}

\section{Hosted file}

manuscript.pdf available at https://authorea.com/users/384349/articles/510571-variationof-runoff-between-southern-and-northern-china-and-their-attribution-in-the-qinlingmountains-china 

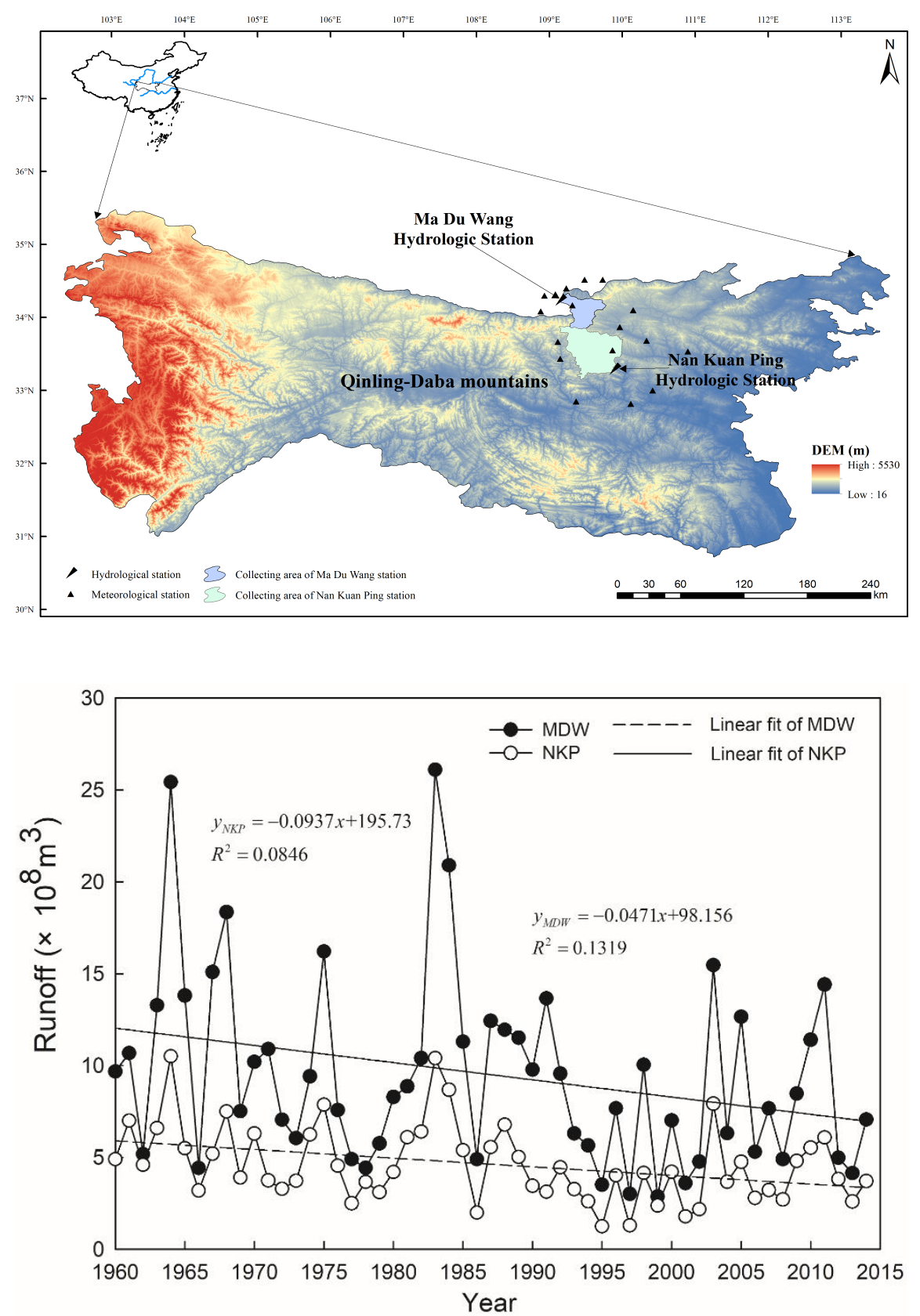

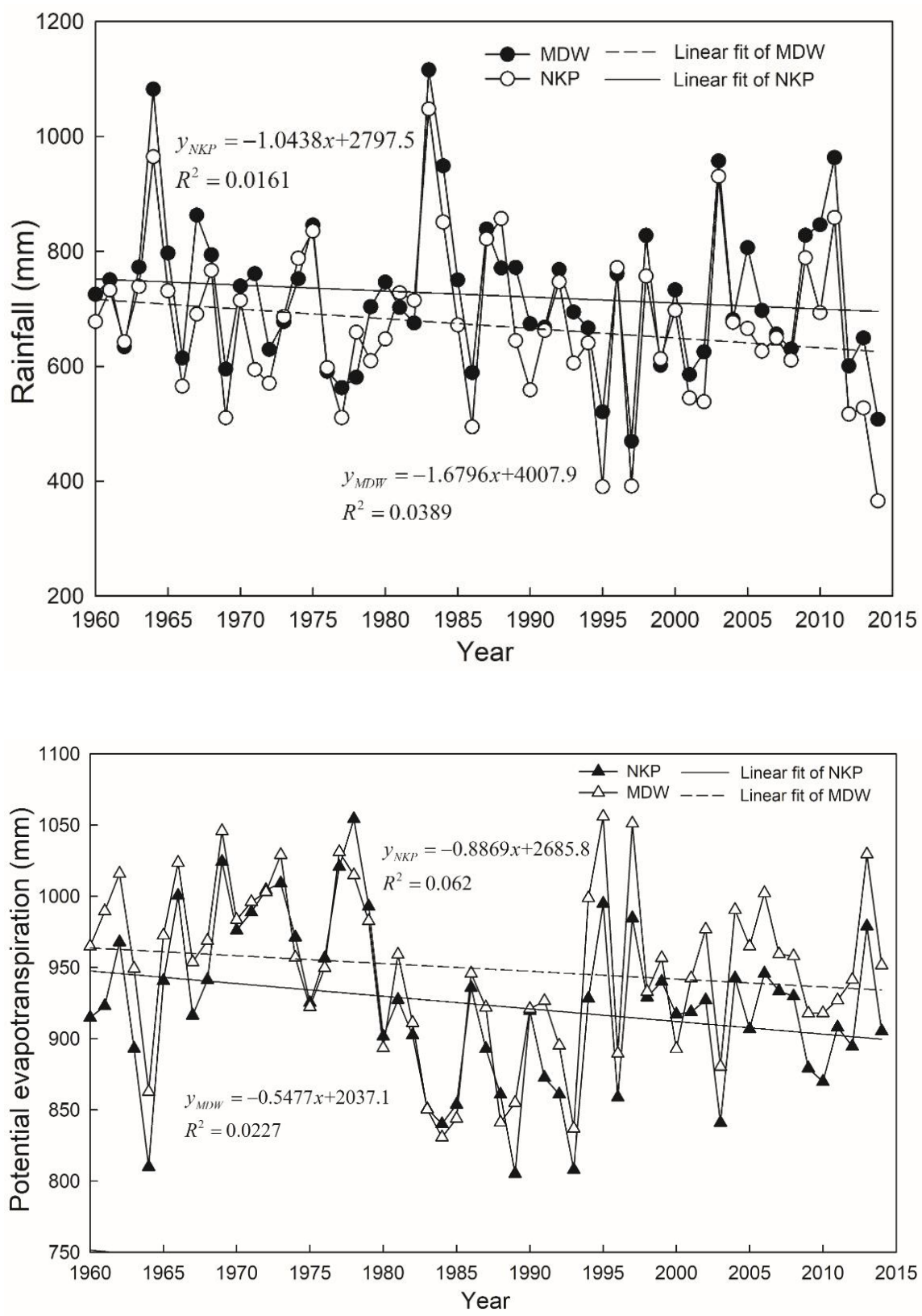

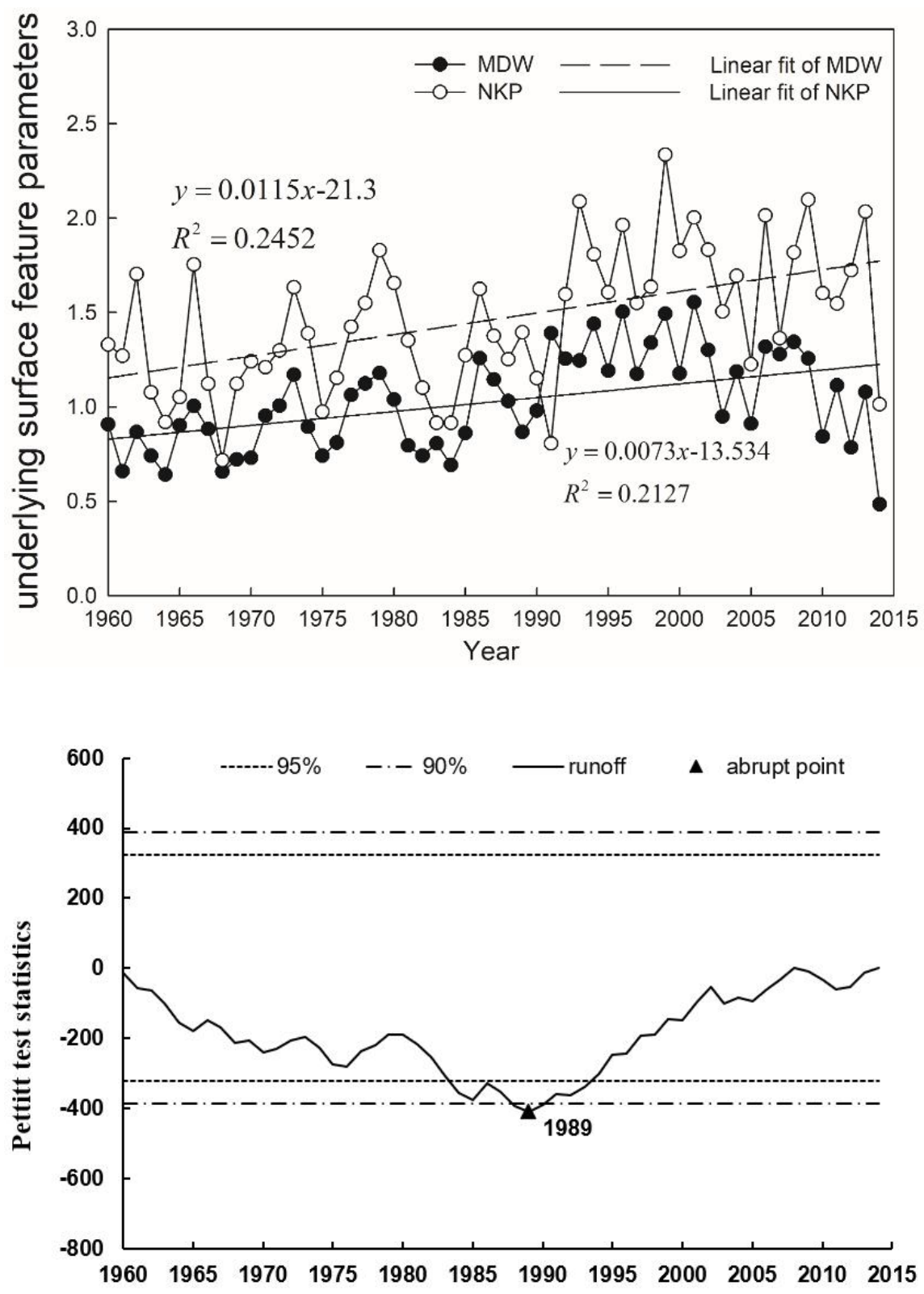

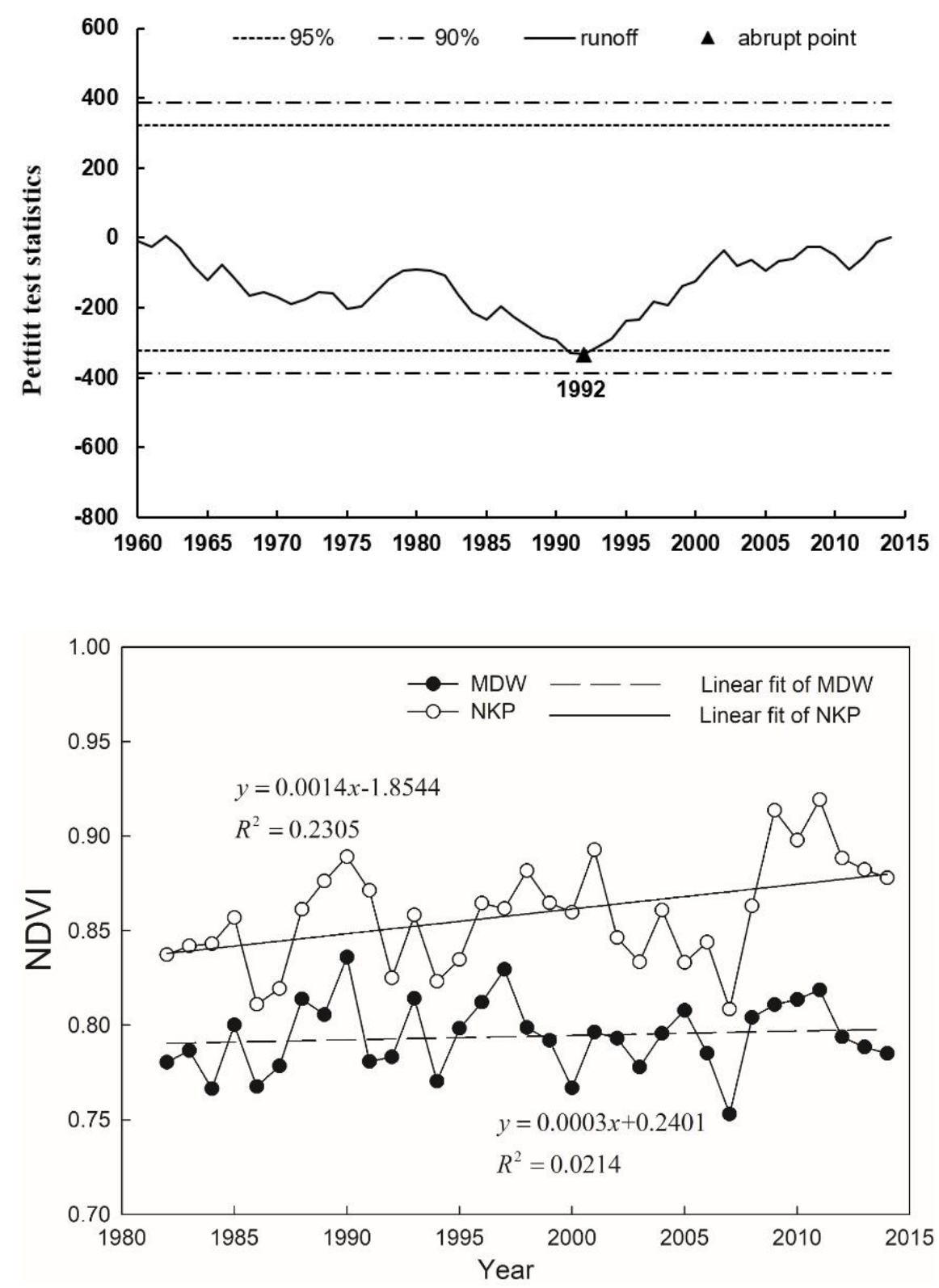

\section{Hosted file}

TABLE 1.pdf available at https://authorea.com/users/384349/articles/510571-variationof-runoff-between-southern-and-northern-china-and-their-attribution-in-the-qinlingmountains-china

\section{Hosted file}

TABLE 2.pdf available at https://authorea.com/users/384349/articles/510571-variationof-runoff-between-southern-and-northern-china-and-their-attribution-in-the-qinlingmountains-china

\section{Hosted file}


TABLE 3.pdf available at https://authorea.com/users/384349/articles/510571-variationof-runoff-between-southern-and-northern-china-and-their-attribution-in-the-qinlingmountains-china

\section{Hosted file}

TABLE 4.pdf available at https://authorea.com/users/384349/articles/510571-variationof-runoff-between-southern-and-northern-china-and-their-attribution-in-the-qinlingmountains-china

\section{Hosted file}

TABLE 5.pdf available at https://authorea.com/users/384349/articles/510571-variationof-runoff-between-southern-and-northern-china-and-their-attribution-in-the-qinlingmountains-china 